\title{
Teachers' Beliefs as Facilitators in Effective English Language Teaching and Learning
}

\author{
Murdani* \\ Graduate School \\ Universitas Negeri Yogyakarta \\ Yogyakarta, Indonesia \\ murdanimurdani15@gmail.com \\ Irvan Effendi \\ Graduate School \\ Universitas Negeri Yogyakarta \\ Yogyakarta, Indonesia \\ irveffendi@gmail.com
}

\author{
Erna Andriyanti \\ Graduate School \\ Universitas Negeri Yogyakarta \\ Yogyakarta, Indonesia \\ erna.andriyanti@uny.ac.id \\ Nurfadilah Nadjib \\ Graduate School \\ Universitas Negeri Yogyakarto \\ Yogyakarta, Indonesia \\ dilanadjib@gmail.com
}

\begin{abstract}
Teachers' beliefs have a greater role than the teachers' knowledge of planning lessons. Despite their significant role in teaching and learning, studies of teachers' beliefs in Indonesian EFL setting are still rare that this paper is to reveal teachers' beliefs as facilitators in effective English language teaching and learning. The participants in this qualitative study, two teachers and five students were interviewed. The data were then transcribed, interpreted, and coded, and categorized by applying thematic data analysis. Regarding the questions of what beliefs teachers hold, the finding shows that the teachers have very well beliefs that they want to become good facilitators for their students in learning English. In relation with the extent of facilitating the students in gaining knowledge, the finding shows that the teachers use mix and match, collaboration between teacher and teacher, team games tournament, three-phase technique, scientific approach and discovery learning. To conclude, the formation of teacher beliefs will have a substantial effect on language teaching and learning process and will bring about an upgrade in students' language abilities. This research is expected to provide information to teachers regarding their beliefs as facilitators.
\end{abstract}

Keywords-Teachers' Beliefs, Facilitators, Effective English Language Teaching and Learning

\section{INTRODUCTION}

Teachers' beliefs are important in evaluating teaching because teachers bring a series of plans based on what they believe into the classroom such as what they want to achieve and how they think (Wan, Low, \& Li, 2011). Teachers' beliefs are significant ideas in comprehending teachers' thought processes, teaching methods, and learning to teach (Zheng, 2009). Beliefs have a key role in language teaching. They help the persons make sense of the world, impacting how new information is understood, and whether it is accepted or rejected $(\mathrm{Xu}, 2012)$. Teachers' beliefs toward something affect what they accomplish in their classroom, their attitudes, and their learners' belief. Teachers' beliefs have a greater role than the teachers' knowledge on planning their lessons, on the types of decisions they adopt, and on classroom activities. Teachers' beliefs strongly predict what decisions and classroom activities the teachers will take and implement in the teaching process (Pajares, 1992).

However, in Indonesia, many teachers have not recognized the importance of the effects of their belief towards their teaching. Indonesian teachers still need to join a workshop or training to receive more information and to gain more knowledge. (Karmina, 2018) and teacher beliefs can cause poor performances in English language learning (Suryanto, 2014).

Beliefs are arguments that can be held consciously or unconsciously, which have an evaluative nature because they are accepted and believed to be true by individuals, and therefore, have emotional commitment; furthermore, it serves as a guide for behavior and thinking (Borg, 2001).

Another belief that teachers should consider is about learning. It is impossible to think about teaching in isolation from learning. Teachers' beliefs about what learning is will affect what they do in the classroom. Even though teachers might be spontaneous persons who rarely plan what they will do in the classroom, their actions nevertheless are derived from their belief that may never have been articulated or made explicit ( $\mathrm{Li}, 2012)$. These teachers can only be really effective if they have a clear understanding of what learning is because only then they can know what kinds of learning outcomes they want their learners to achieve (Xu, 2012).

Several teachers especially senior ones believe that they will feel more powerful when they become the center of the class(Meighan \& Meighan, 1990). Therefore, they tend to always use teacher-centered in the teaching and learning process. They tend to form beliefs early in life, are resistant to change and are culturally bound (Williams \& Burden, 1997). They are tightly related to what we know and think, but offer affective filters that distort, filter, redefine, or reshape information processing and subsequent thinking (Nespor, 1987). Thus, belief is a proposition that may be consciously or unconsciously held, evaluative in that case accepted as true by the individual, and therefore inspired by emotional commitment; this serves as a guide for thinking and behaving(Borg, 2001). Beliefs are part of the process of understanding how teachers shape their work that is 
important for understanding their teaching methods and their decisions in the classroom(Gilakjani \& Sabouri, 2017). Therefore, belief is an important key role for the teacher in the classroom for practices and teacher's professional development.

Teachers' beliefs refer to guide teachers' thinking and action. Further, teachers' beliefs, practices, and attitudes are crucial for understanding and improving educational processes(Chan, 2014). Investigating teachers' beliefs toward the role of facilitators will help them change their methods of teaching and learning over time in order to bring about more improvement for language learners (Gilakjani \& Sabouri, 2017).

In order to empower learners to take charge of their learning, the teacher can adopt the role of facilitator (Auerbach, 2001). Teachers must adopt the role of facilitators for learning, very similar to personal trainers in the gym, guiding trainees to do the right exercises, adjusting "weights", or cognitive burdens (Gynnild, Holstad, \& Myrhaug, 2007), while encouraging and supporting training participants, and ultimately making the trainees supervised and self-regulated. Therefore, this paper addressed the questions of what beliefs do the teachers hold in conducting English teaching and learning process and to what extent do English teachers facilitate their students in gaining knowledge.

Elizabeth Hartnell-Young (2000) concludes that the transition from facilitator to knowledge builder implies that the teacher acts in the practice community, which requires mutual willingness and supportive leadership. Where participants take risks, reflect on experiences and share their learning, they build organizational knowledge and develop individual skills. The role of knowledge development is well developed in elementary schools in this study, where the teaching team uses collaborative planning, reflective journal writing, and video conferencing. In secondary schools, teachers experiment with the application of new technologies but generally do not reflect systematically on their practices or roles, or collaborate on their daily work, partly because of the pressure they perceive as fulfilling their individual obligations to teach various classes. The projects described in this paper show that curriculum projects that are purposeful, collaborative and supported provide professional development tools for knowledge development that can occur through the teacher's daily work (Hartnell-young, 2000).

Winnie Laifan Chan (2014) stated that The results of her study indicate that teacher-teaching beliefs do not change cording to the principles underlying curriculum innovation, which are the main factors that hinder their implementation. It seems that the teachers receive training in implementing curriculum innovations that are important for changing teacher beliefs, which can affect their innovation adoption(Chan, 2014).

Gilakjani and Sabouri (2017) reviewed several important problems related to teacher beliefs in language teaching and learning. Teacher confidence influences what they say and do in the class that shapes their beliefs. Teacher confidence influences teacher awareness, teaching attitudes, and teaching methods. Teacher beliefs affect their teaching behavior, student development, guide their decision-making and interaction with their students. Confidence helps teachers shape planning, curriculum decisions, and identify what must be taught in class. Overall, it can be concluded that teacher trust will have a large effect on the formation of active teaching methods and will bring considerable progress in students' language skills (Gilakjani \& Sabouri, 2017).

\section{RESEARCH METHOD}

\section{A. Research Design}

This study applied a qualitative method because of the nature of the raising problems. To uncover problems related to one's experience when faced with certain phenomena (as stated in the title), is more appropriate to use this method. This method is also suitable to provide complex details about phenomena that are difficult to express by quantitative methods.

\section{B. Research Site}

This study was conducted at a Senior High School located in Sleman, Yogyakarta. This school was chosen because the school is known as having qualified English teachers. Revealing their beliefs as facilitators and how they acted based on their beliefs would be useful to understand how beliefs play important roles in teachers' actions or behaviors. The school has two senior teachers that have many experiences in teaching English. For those reasons, this research is worth carrying out as the initial step to get complete information on teachers' beliefs that may predict their teaching decisions, classroom practices, and problemsolving.

\section{Participants}

Two teachers and five students were chosen to be interviewees. Both English teachers have more than tenyears experience in teaching English at Senior High School. Students at this point provided data to cross-check the teachers' data. The decision to investigate teachers with extensive experience is in line with McMillan and Schumacher (2001, p. 401) and Creswell's (2008, p. 523) suggestion to have study participants who are knowledgeable and fully informed about the study investigated. Besides, the sole participant helped the researcher to fully focus on the teachers' beliefs. The participant above was optimized to obtain the best possible data from interviews(McMillan, $\mathrm{H}, \&$ Schumacher, 2001)(John W, 2008).

\section{Data collection \& Instrument}

The researchers collected data by using the interview for the teachers and the students to be answered which have been theoretically validated. In conducting this research, the researchers did not ask all the sixteen questions because the teachers already answered it while we asked the question that in line with the next question.

The interview was conducted to find out what beliefs do the teachers hold in conducting English teaching and learning process and to what extent do English teachers 
facilitate their students in gaining knowledge. The interview was undertaken with the individual teacher for about 10 to 15 minutes upon the completion of the lesson. The interview was to get in-depth information about how teachers' beliefs intervene in their decisions in overcoming problems that usually occurred in the teaching and learning process.

A list of questions to be covered was given to the teacher before the interview. (The list of guiding questions can be seen completely at Appendix). Then, in accordance with Kvale's and Dawson's suggestion, interviews were done by asking questions orally, speaking in Bahasa Indonesia and the teacher was told beforehand to train before being recorded. To follow Kvale and Dawson (2009), the interview is conducted according to interview guide that focuses on certain themes and include suggested questions to be transcribed, and the written text together with the recording are material for the subsequent interpretation of meaning (Steinar, 1996). Strong principles are part of teachers' beliefs that the theme of the interview of this study was to explore and understand whether teachers have strong principles that they use as the framework of their roles as language teachers.

\section{E. Data analysis}

The data in this study were analyzed after the researchers conducted the interview. The teachers were interviewed to elicit their beliefs as facilitators. While students were interviewed to provide data related to how their teachers' beliefs are manifested or reflected in their teaching. The analyses and interpretation were carried out based on the result of the interview. In real situations, theoretically, the teacher is assigned as a facilitator. Teacher must play seven roles to provide students with the comprehension of how should they act in the classroom (Kudryashova, Gorbatova, Ryabushkina, \& Ivanova, 2016). These teachers' roles are related to the $5 \mathrm{E}$ instructional model that was developed by the Biological Science Curriculum Study (BSCS) in 1987. The 5E instructional models are Engage, Explore, Explain, Extend/Elaborate, and Evaluate. Furthermore, the seven teachers' roles are: Motivator (motivates students for learning), Authority (provides students with ready-made concepts), Controller (controls that students make progress), Trainer (trains students to practically apply the previously acquired knowledge and skills), Moderator (moderates students' learning), Facilitator (facilitates the use of previously acquired knowledge and skills in new situation), Leader (stimulates students to reflect on their progress).

During the transcription stage, the teachers' name was replaced with a pseudonym (Silverman, 1993). Then, the transcripts were given back to the teachers to make sure that it was indeed what they meant. In the effort to maintain validity, the researcher also conducted member checks by sending back (Sharon F \& Gretchen B, 2009) (John W, 2008) (Steinar, 1996) the transcripts of interview results to the participant who had been interviewed to ensure that the results were appropriate with her given responses After that, the transcripts were condensed into briefer statements by rephrasing them into shorter ones (Steinar, 1996). Finally, data were coded and categorized by applying thematic data analysis in line with the focus of this study that is to find out the teachers' belief as facilitators in effective English language teaching and learning.

At last, all of the data obtained from teachers and students interviews were triangulated by making comparisons and contrast to get the in-depth information to enhance validity and to gain accuracy of the conclusion of this study(Marshall \& Rossman, 2006). This part had drawn the qualitative study, particularly the interview study design, as the methodology of the study. Therefore, the data were collected by means of the interview. Consequently, all the data obtained were analyzed qualitatively to be compared and contrasted or triangulated to enhance validity.

\section{FINDING AND DISCUSSION}

A. Beliefs that the teachers hold in conducting English teaching and learning

The most resilient or fundamental teachers' beliefs are formed on the basis of teachers own schooling as young students while observing teachers who taught them. Constructivist theories of teacher development see the construction of personal theories of teaching as a central task for teachers. Such theories are often resistant to change and serve as a core reference point for teachers as they process new information and theories(Golombek, 1998).

Subsequent teacher education appears not to disturb these early beliefs, not least, perhaps, because it rarely addresses them. The most resilient or essential teachers' beliefs are formed on the basis of teachers' own schooling as young students or while observing teachers who taught them (Clark \& Peterson, 1986, summarized and discussed in Breen, ms., page 47-48). Can be seen in Teacher's 1 statement below:

"I like English language lesson since I was in my Senior High School ..., ... Alhamdulillah I could continue my study in IKIP, actually yah as I said, I loved English language and my score in English language lesson is considered high so I should become an English teacher."

Different with Teacher 1, Teacher 2 said that he chose to become a teacher because he wants to devote himself in the world of education and get an adequate salary, as presented below:

"I want to devote myself in the world of education and get an adequate salary"

Furthermore, Teacher 1 believes that English language is an important language because it uses in nearly all aspects of our daily life.
"Incredibly important, every day we are faced with English, Smartphone's instructions are in English, product brands are English, and we cannot be separated from English. So many funny advertisements on the sidewalk, all of them use English. For example, Chinese food, typos, fried chicken, typos, then tailor, typos, and them, they are important, pay attention to it."

Supported with Teacher 2's statement who said, 


\begin{abstract}
"English education is very important because it is used internationally in all aspects of life in society."
\end{abstract}

Spoken English is the most important of the four language skills in the world that is increasingly globalized today (Manan \& Shamsudin, 2012). The purpose of speaking skills is to develop communicative competencies that are important in enabling students to use language in the various functions that they serve in real life(Nair, 2000).

When doing this research, the researchers found some interesting points about methods that the English teachers use in the teaching and learning process and how they facilitate their students in gaining knowledge. Teacher 1 stated that she uses mix and match, team games tournament in teaching English. When the researchers asked about what activity she used for teaching English, the teacher said:

"... then, mix a match, teacher and teacher, team games tournament, STAD, that kind of thing."

This statement supported by their students. Student 4 said that,

"This is the most interesting grade since I entered this school; it is because the teacher provides us such kind of games"

Student 1 stated that,

"hmm,, The class is enjoyable, how it is not, the teacher teaches us with games to make us understand, and the class is not frustrating"

Student 2 said that,

"....this class is interesting and there is game in it..."

Student 5 stated that,

"....in order not to feel bored, the teacher uses game and alike......"

Student 3 also gave the same idea,

"....the way the teacher teaches us is not monotonous, I like it......"

And when the teacher was asked about which method she uses for teaching, is it teacher-centered or student-centered, the teacher answered:

\section{"I mix both of them."}

She mixes the student-centered method and teacher-centered method because the teacher believes that it is better to use both methods for teaching English. As a teacher in this modern era, the student-centered method should be used because the student-centered method has some benefits, such as the method prepares students to be ready to face the real world situation because when the teachers use this method as their methodology of teaching, they will give more opportunities for the students to explore their ability. The students will be more critical towards things that they need and what goals they want to achieve. They get more control over how they spend their time and they get to collaborate with other students. Meanwhile, when the researchers asked about which method the teacher 2 use in the teaching and learning process, he answered:

\section{“... students-centered because teacher is only as a facilitator."}

B. To what extent do English teachers facilitate their students in gaining knowledge.

About how these two teachers facilitate their students in gaining knowledge, the first teacher said: "through mix and match, collaboration between teacher and teacher, and team games tournament". While the second teacher stated: "through three-phase technique, scientific approach, or discovery learning."

Through the lecturer, learning model can help students apply ideas, get information, skills and ways of thinking. The learning model also functions as a guide for learning designers and for lecturers in planning teaching and learning activities (Agus, 2013). Mix and Match method allows teachers to combine modern language teaching methods for maximum learning, collaborating with other teachers gives a different impression and new atmosphere for students so that learning becomes more enjoyable and in that way, the teacher will also get emotional support, team games tournament will motivate students to compete and therefore will make them more active in learning, three-phase technique helps students to know the process of prewriting, writing, and revising stage, scientific approach will help students to think critically and to develop their high-thinking level and discovery learning gives students the opportunity to explore and collaborate with teachers and peers to solve problems.

The students love and respect towards their teacher will be reflected in the performance of student involvement in the teaching and learning process. moreover, providing learning where students engage in fun learning tasks, will increase their learning enjoyment. To reach this, the teacher must provide learning opportunities and design educational activities that are appropriate to attract students (Al-shara, 2015).

Teaching English as a foreign language (TEFL) has become very popular during the last century and the foundation has been set to this discipline. Teachers face different kinds of problems that make the process slow and rather weak. These problems put teachers into a dilemma in dealing with all the hardships in teaching students for the sake of their future. Based on the teacher 1's and teacher 2's answer, they said that one of the problems that they always faced in the English teaching and learning process is that the students are lack of vocabulary.
"Ah there are many problems, hmm they are lacking of vocabulary. We have to work extra hard. Sometimes I have to type the vocabulary for them, for example when we discuss about a text; if I have a lot of time, I will type it for them and leave some parts of the text empty and ask them to fill in the blank and translate the word. If they can't answer it, I will help them translate it directly because we don't have many times to wait for them to finish the task."- Teacher 1 
"The students lack vocabulary." - Teacher 2

The answer from the teacher 1 and 2 indicated that the senior high school students in this particular school in Sleman lack vocabulary and they (Teacher 1 and Teacher 2) have to work really hard to teach the students vocabulary. Teacher 1 stated that vocabulary is a basic element in English. Therefore, they have to make sure that the students' vocabulary increases. This was supported by Yunus, Sulaiman, Kamarulzaman, and Ishak, (2013) that common difficulties in learning English faced by intelligent students related to speaking English, lack of vocabulary, grammar, and speaking skills are the most difficult to learn. In an environment of people who are not native speakers to speak English it is difficult to be able to speak accurately and smoothly like native speakers (Ting, Mahadhir, \& Chang, 2011).

"knowledge of vocabulary is central to communicative competence and for second language acquisition"(Schmitt, 2000).

Another challenge that the English teachers face in the classroom is the low motivation of the students to learn English.

"Nowadays students' passion to learn English is low. Therefore, we as a teacher have to do our best to engage our students; to make them willing to learn English. For example, if they like to watch movie we should show them a video. If they like to listen to music, we have to play some music for them. But we cannot do that all the time because we have limited time and there are many materials that we should transfer to them."- Teacher 1

\section{"Their motivation is low."- Teacher 2}

The analysis of the interview result shows that both of the teachers face the same problem in English teaching and learning process. The first problem is that the learners lack vocabulary and they have low motivation to learn English. Therefore, both of the teachers have to do their best in teaching the students. The success of each action depends on the extent to which people try to achieve their goals, along with the desire they have in order to do so. Generally, people refer to this psychological factor - the drive that produces action - as a motivation. This is the power of motives that arouse, incite, or stimulate action. Motivation is an important factor in determining students' readiness to communicate (Pourhosein Gilakjani, A., Leong \& Saburi, 2012). Motivation makes participants have goals and directions to follow. Hence, it has a major role in language learning. Due to a lack of sufficient motivation, some difficulties may occur to students. Without a strong desire to learn, it is very difficult for students to obtain effective learning(Alizadeh, 2016).

\section{CONCLUSION}

As facilitators, teachers play a role in providing services to facilitate students in the learning process. Regarding the questions of what beliefs teachers hold, the finding shows that the teachers have very well beliefs that they want to become good facilitators for their students in learning English. In relation with the extent of facilitating the students in gaining knowledge, the finding shows that the teachers use mix and match, collaboration between teacher and teacher, team games tournament, three-phase technique, scientific approach and discovery learning. The teachers provide methods that are appropriate and fun for students so that students can capture the lesson without feeling burdened.

The study leads to some implications. First, the study offers teachers to1) increase their awareness that teachers' beliefs are crucial for teaching and learning 2) identify the factors that make teachers have wrong beliefs 3 ) engage in ongoing professional development that ultimately improves their teaching performance.

For further research, it is important to conduct research on teacher beliefs and their teaching practices then similar studies can be carried out on a larger scale to have a broad view of the beliefs teachers have.

\section{REFERENCES}

Agus. (2013). Cooperative Learning. Yogyakarta: Pustaka Pelajar.

Al-shara, I. (2015). As Realized By The Students: A Survey From The Learning And Teaching Between Enjoyment And Boredom As Realized By The Students: A Survey From The Educational Field. European Scientific Journal, 11(7), 23.

Alizadeh, M. (2016). The Impact of Motivation on English Language Learning. International Journal of Research in English Education, 1(1), 11-15.

Auerbach, E. (2001). Creating participatory learning communities: Paradoxes andpossibilities. In J. Hall and W. Eggington (Eds.), The sociopolitics of Englishlanguage teaching. Clevedon: Multilingual Matters.

Borg, M. (2001). Key concepts in TLT: teachers' beliefs. ELT Journal, 49, 72-80.

Chan, W. L. (2014). Hong Kong secondary school English teachers' beliefs and their influence on the implementation of task-based language teaching. Hong Kong: English Language Education and Assessment.

Gilakjani, A. P., \& Sabouri, N. B. (2017). Teachers' belief in English language teaching and learning: a review of literature. Canadian Center of Science and Education, 10(4), 79-86.

Golombek, P. . (1998). A study of language teachers' personal practical knowledge. TESOL Quarterly. Tesol Quarterly, 19, 487-500.

Gynnild, V., Holstad, A., \& Myrhaug, D. (2007). Teaching as coaching: A case study of awareness and learning in engineering education. International Journal of Science Education, 29, 1-17.

Hartnell-young, E. (2000). From Facilitator to Knowledge-Builder : A New Role for the Teacher of the Future. Centre for Applied Educational Research, 132, 159-163.

John W, C. (2008). Educational research: planning, conducting, and evaluating, quantitative and qualitative research. New Jersey: Pearson International Edition.

Karmina, S. (2018). Indonesian Teachers 'Beliefs about Cooperative Learning. 5(2), 1-7.

Kudryashova, A., Gorbatova, T., Ryabushkina, S., \& Ivanova, E. (2016). Teachers' roles to facilitate active learning. Mediterranean Journal of Social Science, 7, 1-7.

Manan, A. A., \& Shamsudin, S. (2012). Comparing Form Four Malay and Chinese Students' Spoken English. The English Teacher, 1, 1-14.

Marshall, C., \& Rossman. (2006). designing Qualitative Research. USA: Sage Publication INC.

McMillan, H, J., \& Schumacher, S. (2001). Research in education: aconceptual introduction. Fifth Edition. New York: Longman.

Meighan, R., \& Meighan, J. (1990). Alternative roles for learners with particular reference to learners as democratic explorers in teacher education courses. The School Field.

Nair, M. A. (2000). Teaching of English as a Foreign Language. Utusan 
Publication.

Nespor, J. (1987). The role of beliefs in the practice of teaching. Journal of Curriculum Studies, 19, 317-328.

Pajares, M. . (1992). Teachers' beliefs and educational research: Cleaning Up a Messy Construct. Review of Educational Research, 62, 307332.

Pourhosein Gilakjani, A., Leong, L. M., \& Saburi, N. B. (2012). Study on the Role of Motivation in Foreign Language Learning and Teaching. Modern Education and Computer Science, 7, 9-16.

Schmitt, N. (2000). Vocabulary in language teaching. Cambridge: Cambridge University Press.

Sharon F, R., \& Gretchen B, R. (2009). Ethics and trustworthiness. United Kingdom: Palgrave Macmillan.

Silverman, D. (1993). Doing qualitative research Second Edition. London: Sage Publications.

Steinar, K. (1996). Inter Views: An Introduction to qualitative research interviewing. New Delhi: Sage Publication.

Suryanto. (2014). Issues In Teaching English In a Cultural Context : a Case of Indonesia. 1, 1-9.

Ting, S. H., Mahadhir, M., \& Chang, S. L. (2011). Fluency in Spoken English and Use of English by University Students. Serdang: Universiti Putra Malaysia Press.

Wan, W., Low, G., \& D. Li, M. (2011). From students' and teachers' perspectives: Metaphor analysis of beliefs about EFL teachers' roles. Dicle Üniversitesi Ziya Gökalp Eğitim Fakültesi Dergisi, 22, 230-247.

Williams, M., \& Burden, R. L. (1997). Psychology for Language Teachers: a Social Constructivist Approach. Cambridge: Cambridge University Press.

$\mathrm{Xu}$, L. (2012). The Role of Teacher s ' Beliefs in the Language Teachinglearning Process. Theory and Practice in Language Studies, 2(7), 1397-1402. https://doi.org/10.4304/tpls.2.7.1397-1402

Yunus, M. M., Sulaiman, A., Kamarulzaman, M. H., \& Ishak, N. M. (2013). Language Learning Difficulties Among Malaysian Gifted Students. Asian Social Science, 9, 1-8.

Zheng, H. (2009). A review of research on EFL pre-service teachers' beliefs and practices. Journal of Cambridge Studies, 4(1), 73. 